\title{
Institutional Mechanism of Functioning of the Labor Market in the Conditions of the Market Economy of Ukraine
}

\author{
Yevheniia Druhova 1 [0000-0001-6218-4763], Yana Koval ${ }^{2 *[0000-0001-6578-2996]}$
}

\author{
${ }^{1}$ Vadym Hetman Kyiv national economic University, Kyiv, Ukraine \\ 2 “KROK” University, Kyiv, Ukraine \\ *koval_y.s@uk.net
}

\begin{abstract}
The development of the national economy is largely determined by the functioning of the labor market and the peculiarities of the use of labor resources. The labor market characterizes the relationships that develop in the process of hiring and evaluating the labor force and reflects the Coordination of interests between employers, employees, the state and public organizations. The issues of measuring the impact of the institutional structure on economic processes during the unfolding global financial and economic crisis have become particularly relevant. The scientific and practical experience of developed countries has shown that during this period, effective rules and regulations can stabilize the economy, while providing significant resource savings. In these conditions, the professional, qualification and educational sign of supply and demand in the labor market should correspond to the stable development of the economy. There is an urgent need for a scientific analysis of the functioning of the labor market in Ukraine and the development of mechanisms for effective socially oriented and economically justified state policy, since currently the labor market of Ukraine is characterized by its unbalance. Especially relevant is the study of the problems of formation and development of the country's labor market. In this regard, it is of particular importance to identify the institutional foundations for the formation and development of the labor market.
\end{abstract}

Keywords: mechanism, labor market, Public Administration, institutional mechanism, employment of the population.

\section{INTRODUCTION}

In the context of the increasing impact of globalization processes, including on the Ukrainian economy, the key role is played by human potential, which is the most important driving force for innovative development. It is the availability of highly qualified specialists that is the basis for the competitiveness of the national economic model of the European state in the global system of the world economy. The development and realization of human potential is possible due to the well-coordinated functioning of all elements of the economic system, in particular the labor market, which interacts with the market of educational services, the state, and social infrastructure.

\section{RESEARCH ANALYSIS}

Issues of the mechanism of functioning of the labor market and its individual aspects are depicted in the research of foreign scientists: A. Pigou [1], V. Pareto [2], P.A. Samuelson [3], in particular domestic scientists such as: E. M. Libanova [4], R. O. Kulinicha [5], O.V. Dlugopolsky [6], V.M. Geets [7], I.G. Mantsurov [8] and other scientists. A multi- vector study of the methodological foundations that measure the effectiveness of the functioning of the labor market mechanism in economics is carried out by [9]: Analysis of the current state and dynamics of gross domestic product (GDP) and inequality in the distribution of income (wealth). Measuring the quality of human and intellectual capital development. Measuring the level and quality of life.

In this manner, today there are different approaches to measuring such a complex socio-economic phenomenon. Quantitative and qualitative assessment of the level of material well-being, depicts a statistical analysis of the main indicators that characterize the state of the market and forms further directions of state policy in order to ensure a decent level of well-being of the population.

\section{RESEARCH RESULTS}

The development of the national economy is largely determined by the functioning of the labor market and the peculiarities of the use of labor resources. The labor market characterizes the relationships that develop in the process of offering, hiring and evaluating the labor force and reflects the adjustment of interests between 
employers, employees, the state and public organizations.

The labor market is the most complex and controversial element of a market economy. Here the interests of the worker, employer and state are intertwined in determining the price and working conditions of work. The effective mechanism of functioning of the labor market depends on the demand for labor and its supply, and accordingly, the unemployment rate, and as a result, the standard of living of the population. The level of inflation and the loan interest rate determine investment activity, which, in turn, shapes the movement of the job system: their number increases or decreases, new ones are created. The level of income of the population depends on the degree of its labor activity, which in particular turns an economic person (homo economicus) into a creative person (homo creator) as a free individual;

Features of the functioning of the labor market and the use of labor resources in Ukraine in the context of the deployment of transformation processes are: noncompliance of the professional and qualification composition of labor resources with the structure of production; excess labor force; spread of unregulated employment; latent unemployment; a fairly high level of load on one workplace and its significant differentiation in the context of regions of the country.

The consequences of the imperfection of the institutional mechanism for the functioning of the labor market are extremely negative. Today, a quarter of the country's population has incomes below the subsistence level. The property stratification of society has reached unprecedented proportions. The importance of the problem of improving the economic mechanism of regulating social and Labor Relations for the theory and practice of forming an effective social policy, as well as the complexity and scale of the problem require serious theoretical understanding, methodological and methodological developments, primarily based on a systematic approach to its solution.

In addition, modern economic theories have not yet developed a unified approach to substantiating the mechanisms of labor market regulation and employment optimization. This is due to the complexity of the processes taking place in the modern economy, continuous changes in the labor market, and its growing dependence on many socio-economic, cultural, ethnic, and institutional factors.

The main purpose of the functioning of the labor market mechanism is to increase the level of socioeconomic development of each region of the country, which is ensured by activating the activities of business entities: the population, the state and enterprises. A significant influence on the functioning of the mechanism is exerted by one of the main institutions - the state, in the form of legislative documents and programs for the socio-economic development of the region and the country as a whole. Legislative power is based on a set of laws on the functioning of all business entities.

Today, economists distinguish the following principles of functioning of the labor market mechanism: the principle of legislative support, which provides for the legal differentiation of the parties, subjects and regulatory institutions of the labor market, the procedure for their interaction, guarantees of activity, establishes a number of other legal bases for functioning; the principle of partnership, which provides for the defense and protection of the parties ' interests on the basis of cooperation, mutual agreements, approvals, compromise solutions; the principle of universality means the extension of Minimum Norms and guarantees to all subjects of Labor Relations without exception, and therefore, the guarantee and mandatory application of state minimum social standards; the principle of targeting complements and develops the principle of universality and requires a differentiated, targeted approach to protecting and supporting certain categories of the population. This approach should apply primarily to those categories of the population that are already or still unable to protect themselves (this applies to disabled people, single-parent families, single mothers, large families, etc.); the principle of integration, which implies the mandatory interrelation and interaction of all forms, elements and methods of Social Protection, their organization into a single system at all levels;

The current organizational environment of Ukraine can determine the role and functions of the labor market mechanism in the economic system, that is, functioning if possible of changes and reconstructions. Consequently, the country, in order to ensure the sustainability and efficiency of work on the protection of workers ' rights, as one of the components for the proper functioning of the system mechanism in this market, includes the creation of three-way Labor Relations, which include: the state, trade unions and entrepreneurs. The essence of these relations is to find a compromise between representatives of the state, employers and trade unions as defenders of employees. On the basis of these relations, the mechanism for regulating labor behavior includes a set of factors, factors and Means designed to ensure the Coordination of social and economic interests of participants in the labor process.

In this institutional innovation, people have reasons to reorient the roles and functions of the relevant authorities, reconstruct and rationalize expectations and visions, and have high hopes for the government, trade unions, and businesses to take appropriate responsibility. 
Based on a two-dimensional (external and internal environment) representation of the functioning of the market mechanism, the main groups of environmental factors can be distinguished in Ukraine (Table 1).

Under the influence of the factors indicated in the table, there is a formation of the country's social policy, the globalization of the economy, the development of social labor and the formation of institutions that coordinate the interests of all spheres of management.

Table 1. Factors of evolutionary changes in the labor market system

\begin{tabular}{|c|c|c|}
\hline Factors & External factor & Internal factor \\
\hline Economic & $\begin{array}{c}\text { personnel training } \\
\text { system, quantitative and } \\
\text { qualitative characteristics } \\
\text { of personnel }\end{array}$ & $\begin{array}{l}\text { fluctuations in } \\
\text { macroeconomic } \\
\text { indicators, } \\
\text { structural shifts, } \\
\text { scientific and } \\
\text { technological } \\
\text { progress }\end{array}$ \\
\hline Institutional & $\begin{array}{c}\text { changing rules, } \\
\text { standards, instructions, } \\
\text { structure of rights, } \\
\text { obligations, and values }\end{array}$ & $\begin{array}{c}\text { changes in } \\
\text { legislation, labor } \\
\text { market regulation }\end{array}$ \\
\hline Social & $\begin{array}{l}\text { social policy of the } \\
\text { enterprise conflict } \\
\text { resolution through } \\
\text { consultations, social } \\
\text { dialogue }\end{array}$ & $\begin{array}{l}\text { social policy of the } \\
\text { state, changing } \\
\text { ideology }\end{array}$ \\
\hline Political & $\begin{array}{c}\text { changing the political } \\
\text { situation; }\end{array}$ & $\begin{array}{c}\text { changing the } \\
\text { political situation }\end{array}$ \\
\hline Economic & $\begin{array}{c}\text { introduction of } \\
\text { fundamentally new } \\
\text { technologies, re-profiling } \\
\text { of production, changing } \\
\text { the strategy of Human } \\
\text { Resource Development }\end{array}$ & $\begin{array}{l}\text { changing the } \\
\text { nature of economic } \\
\text { policy, economic } \\
\text { reforms }\end{array}$ \\
\hline Institutional & $\begin{array}{c}\text { reorganization, change of } \\
\text { ownership of the } \\
\text { enterprise }\end{array}$ & $\begin{array}{l}\text { and change of } \\
\text { formal rules, } \\
\text { reform of } \\
\text { employment } \\
\text { contract rules }\end{array}$ \\
\hline Social & $\begin{array}{l}\text { conflicts in the team, } \\
\text { Social Policy at the } \\
\text { enterprise }\end{array}$ & $\begin{array}{l}\text { education system } \\
\text { reforms, bursts of } \\
\text { social activity }\end{array}$ \\
\hline Political & $\begin{array}{l}\text { changing the political } \\
\text { system, revolutions }\end{array}$ & $\begin{array}{l}\text { changing the } \\
\text { political system, } \\
\text { revolutions }\end{array}$ \\
\hline
\end{tabular}

Source: developed by the author

Based on the above circumstances, we see the impact on the economic system, since the level of employment, the level of poverty, etc. - determines the overall level of development of the national economy. In the center of the structure, a tariff grid is being formed - which is used by all spheres of economic activity. Thus, the level of income affects the education of a person (which is later transformed into capital) and the formation of informal institutions of the country; migration processes (which are highlighted more as a problem of outflow from the country, rather than as a relief of social tension), and so on.

Thus, the interaction between the factors that form and the factors of the labor market that drive it to development concerns the state of the economic system as a whole in the country and the degree of its integration into international economic institutions. The volume of institutional investment, the nature of institutional barriers, the mechanisms of institutional innovation, the nature of the political system; the ratio of political external and internal forces of influence follows the formation of development factors due to the synergistic effect.

As we can see, the economic factor includes: modernization of production, organization and changes in working conditions, financial situation of the enterprise; relative to the institutional factor (Figure 1).

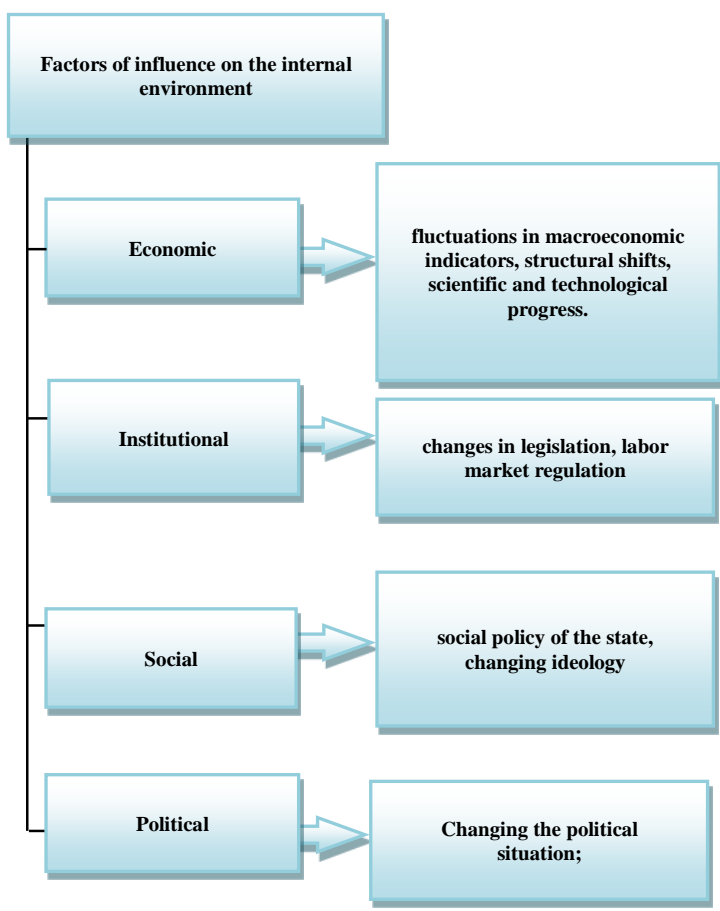

Figure 1 Factors affecting the internal environment

\section{Source: developed by the author}

These are institutional norms, cultural stereotypes, habits, the inability of a person to process a large amount of information, the influence of emotions and feelings, various transaction costs; accordingly, the social factor of influence is defined as the influence on the formation and implementation of socio-economic interest and on economic behavior in general; the latter is a political factor, it has its own specifics, since it exists in the external environment and is defined as state regulation and intervention of the authorities and appropriate levels.

Under the influence of the factors indicated in the schemes, the formation of the country's social policy, the globalization of the economy, the development of social labor and the formation of institutions that coordinate the interests of all spheres of management takes place. Using the example of the social and labor sphere, we can see its impact on the economic system, since the level of employment, the level of poverty, 
etc.-determines the overall level of development of the national economy.

In the center of the structure, a tariff grid is being formed - which is used by all spheres of economic activity. Thus, the level of income affects the education of a person (which is later transformed into capital) and the formation of informal institutions of the country; migration processes (which are covered more as a problem of outflow from the country, and not as a relief of social tension), as well as the mutual influence of all factors on the external environment, the results of which are briefly highlighted in Figure 2.

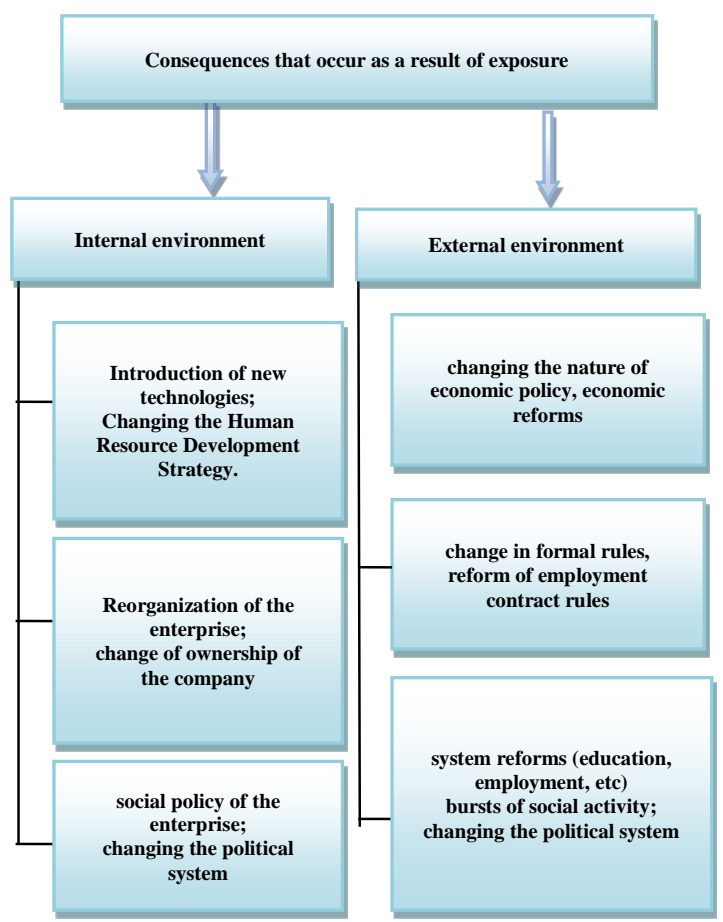

Figure 2 Consequences of factors affecting the external environment

\section{Source: developed by the authors}

Thus, the interaction between the factors that form and the factors of the social and labor sphere that move it towards development concerns the state of the economic system as a whole in the country and the degree of its integration into international economic institutions. The volume of institutional investment, the nature of institutional barriers, the mechanisms of institutional innovation, the nature of the political system; the ratio of political external and internal forces of influence follows the formation of development factors due to the synergistic effect.

The new qualitative state of the social and labor sphere is reflected in the nature of Labor, the organization of Labor, types, forms of economic and labor activity, means and objects of labor; norms of labor activity, labor morality and ethics, etc.

Revolutionary changes come from the organizers of Labor and production at different levels. At the macro level, significant changes in the system of social and labor relations can be made by state executive and legislative bodies through economic policy and lawmaking (macroeconomic reform). Changes are initiated in the rules of Labor Relations and labor organization; the nature and methods of registration of employment contracts; the set of rights and obligations of participants in labor activity; the activities of intermediary institutions in the labor market.

Based on these principles, we can distinguish the following tools for their influence on the regulation of social and Labor Relations:

1. Regulatory and legal regulation of social and Labor Relations. At the state level, social and labor relations are regulated by international treaties that have been ratified in Ukraine, the Constitution and laws of Ukraine, presidential decrees, and resolutions of the Cabinet of Ministers.

The regulatory document of social partnership is the general agreement between the Cabinet of Ministers of Ukraine, the Federation of employers of Ukraine and the Federation of Trade Unions of Ukraine for 20082009 [10]. The current legislation grants an employee the right to exercise their abilities for productive and creative work by entering into a collective agreement at one or simultaneously at several enterprises, institutions, organizations, unless otherwise provided by the legislation, collective agreement or agreement of the parties [11].

Labor Relations at the industry, regional and production levels are regulated, in addition to laws, by a number of normative legal acts: general agreement between the Cabinet of Ministers of Ukraine, employers ' association and trade unions, contracts and agreements at the regional level; industry agreements and agreements; orders and instructions of ministries, committees, departments; decisions of local selfgovernment bodies; local regulatory legal acts-orders of Directors of enterprises, collective agreements and agreements at the level of enterprises, organizations.

2. Collective agreements and agreements. The introduction of collective-contractual regulation in the sphere of social and Labor Relations is connected with theoretical developments in the essence of the social contract, its legal support.

There are a number of objective and subjective factors regulating social and Labor Relations: stabilization of social and Labor Relations,guarantees from the state; independence and independence of social subjects of Labor Relations, their organizational structure; formation of social responsibility of both the employer and employees; dissemination of the practice of democratic management at the level of production enterprises and organizations, in which employees will directly participate in management. 
Studies have shown a low level of awareness of employees regarding the conclusion of collective agreements at their enterprises. According to statistics, most often this information is received at meetings of the labor collective and trade union meetings (40.2 and $36.7 \%$ of respondents indicated, respectively). Other forms of informing are practically not used (bulletin board - 15.4\%, multi - circulation newspapers, bulletins, etc. $-1.6 \%$ ), as a result of which employees are often not familiar with the content of the collective agreement [12].

So, in Ukraine at the moment there is a low level of awareness of employees with collective agreements and agreements, the procedure for resolving collective labor disputes.

Materials of research conducted within the framework of the ILO technical cooperation project "Ukraine: promoting the implementation of basic principles and rights in the field of Labor" gave information that $11.1 \%$ of respondents noted that such a clause of the collective agreement as ensuring social protection against unemployment is being implemented well, while $43.9 \%$ - that this provision is not implemented at all [13].

3. Employment contract. The Labor Code of Ukraine provides for both oral and written forms of concluding an employment contract.

Regulation of social and Labor Relations at the level of industrial organizations according to legislative norms should be provided by an employment contract drawn up in writing. The practice of Labor Relations shows that the most common form of concluding an employment contract is oral. The conclusion of an employment contract is drawn up by an order or order of the employer (or a person authorized by him) on the employee's employment. However, an employment contract is also considered concluded when the order or instruction was not issued, but the employee was actually allowed to work. Thus, under the condition of an oral contract between an employer (or a person authorized by him) and an employee, in the absence of a corresponding local regulatory act, proof of the existence of an employment relationship for an employee becomes much more complicated [14-15].

During the period of formation of market relations in Ukraine in the social and labor sphere, certain positive changes have taken place: the process of denationalization, elimination of the state's monopoly on the use of labor as a result of the emergence of a variety of forms of ownership and management; increased care on the part of employees for maintaining and improving their competitiveness in the labor market; formation of readiness for more productive, intensive work under the influence of increasing competition between employees for jobs.
In Ukraine, a serious obstacle to the formation of perfect, transparent social and Labor Relations is the significant scale of the shadow sector of the economy, in particular, the practice of avoiding taxation, maintaining "double accounting" has spread, with a few exceptions, to almost all spheres of activity. The consequence of this is a distortion of economic indicators, massive non-receipt of taxes to budgets of various levels [16].

At the same time, we note that the formation of a new model of social and Labor Relations in Ukraine is negatively affected by a number of factors: wage differentiation has become significant as a result of the monopoly state of certain enterprises and entire industries; there is a growing" lack of transparency " in social and Labor Relations, which is associated with the scale of the shadow economy, the imperfection of the current labor legislation, and the lack of proper control over its compliance at various levels of management; the efficiency of social partners ' activities in fulfilling their duties remains low, which reduces the effectiveness of the social partnership system in modern conditions.

Labor legislation is the main tool of social and labor relations, through which Labor policies are developed and implemented. Ukraine already has an extensive legislative framework that regulates almost all areas of social and Labor Relations: the Labor Code of Ukraine, the law of Ukraine "on employment", the law of Ukraine "on collective agreements and agreements", the law of Ukraine "on remuneration of Labor", the law of Ukraine "on mandatory state pension insurance", etc.

In addition to legislative regulation, a mechanism for regulating legislative acts is necessary. Such a mechanism is the program and rule-making activities of the state represented by its executive bodies (ministries, departments, regional institutions).

\section{CONCLUSIONS}

So, the institutional mechanism of the labor market in Ukraine today is still not sufficiently developed in comparison with the leading countries. This is manifested, first of all, in the imperfect regulatory framework, the high level of the shadow economy, the lack of control over compliance with legislation and the lack of control over the implementation of the norms of the agreement between the employer and the employee. At the same time, the labor market, which forms the basis of the mechanism of functioning of the social and labor sphere in the economy of Ukraine, today should be considered not only as the basis for regulating employment, but also as the most important prerequisite and component of the mechanism for the formation of new socio-economic relations, qualitative transformation of the entire social system. Changes in property relations, structural adjustment of the 
economy, creation of prerequisites for stabilization and economic growth are directly related to the effective functioning of the mechanism of the social and labor sphere, large-scale release and redistribution of Labor, balancing of jobs and supply volumes in the labor market.

Considering the above, it is possible to form proposals for improving the place of the labor market at the state level: to the system of state regulation of the labor market, it is necessary to apply a comprehensive methodological approach, which includes: determining the demand of state regulation of the labor market; disclosure of its main characteristics; determining the subjects, objects, principles, tasks, types, methods of state regulation of the labor market; in modern conditions, it is necessary to eliminate excessive liberalization of the economy of Ukraine by protecting domestic producers, concentrating resources and state management of the economy in priority sectors for the state, strict control of non-state financial and banking; control of foreign trade in products of enterprises subordinate to the state in order to strengthen the National oriented economy; efficiency state mechanisms for regulating the labor market will largely be determined by how much typical pan-European guidelines of socio-economic policy of supranational organizational entities will be taken into account at the state level, while the influence of the national state on these processes is weakened.

To improve the functioning of the labor market of Ukraine, it is necessary to define common conceptual approaches to assessing the functioning of the labor market, a model of its state regulation, develop directions for a comprehensive study and a system of statistical indicators, according to which specific measures will be identified to improve employment policy in the country.

\section{REFERENCES}

[1] Pyhu, A. (1985), Ekonomicheskaya teoriya blagosostoyaniya [Economic theory of welfare], Progres, Moscow, Russia, 512 p.

[2] Pareto, V. (1953), "On the Economic Phenomenon", International Economic Papers. № 3, p. 184 .

[3] Semiuelson, P.A. and Nordhauz, V.D. (1995), Makroekonomika [Macroeconomics], Osnovi, Kyiv, Ukraine, 544 p.

[4] Libanova, E.M. (2015), "The 2015 Nobel Prize in Economics was awarded for a series of studies on consumption, poverty and well-being", Demohrafiia ta sotsialna ekonomika, № 3 . pp. 11-20.

[5] Kulynych, R.O. (2007), Statystychna otsinka chynnykiv sotsialno-ekonomichnoho rozvytku
[Statistical assessment of factors of socioeconomic development], Znannia, Kyiv, Ukraine, $311 \mathrm{p}$.

[6] Dluhopolskyi, O.V. (2007), "Welfare economics and criteria for its evaluation: a politicaleconomic approach", Nauka y ekonomika, vol. 3 (7), pp. 5-20.

[7] Heiets, V.M. (2009), Suspilstvo, derzhava, ekonomika: fenomenolohiia vzaiemodii ta rozvytku [Society, state, economy: phenomenology of interaction and development], Kyiv, Ukraine, 864 p.

[8] Mantsurov, I.H. (2006), Metodolohiia statystychnoho otsiniuvannia ekonomichnoho zrostannia ta konkurentospromozhnosti krainy [Methodology for statistical assessment of economic growth and competitiveness of the country], KNEU, Kyiv, Ukraine, 306 p.

[9] Libanova, E.M. Hladun, O.M. Lisohor, L.S.ta in. (2013), Vymiriuvannia yakosti zhyttia v Ukraini. Analitychna dopovid [Measuring the quality of life in Ukraine. Analytical report], Kyiv, Ukraine, $50 \mathrm{p}$.

[10] General Agreement between the Cabinet of Ministers of Ukraine, the Confederation of Employers of Ukraine and All-Ukrainian Trade Unions and Trade Unions for 2008-2009 (2020), Pratsia i zarplata, № 6, pp. 10-16.

[11] Andrusenko, N. (2007), "Employment contract. Terms and conditions of its conclusion", Pratsia i zarplata, № 14, pp. 4-5.

[12] Kouz, R. (1993), Problema sotsialnyih izderzhek [The problem of social costs], Delo, Moscow, Russia.

[13] Umang Dhuri and Nilakshi Jain (2020), "Teaching Assessment Tool: Using AI and Secure Techniques", International Journal of Education and Management Engineering, № 3, pp. 12-21. DOI: 10.5815/ijeme.2020.03.02

[14] Jyoti Shokeen and Chhavi Rana (2019), “An Application-oriented Review of Deep Learning in Recommender Systems", International Journal of Intelligent Systems and Applications, №5, pp. 46-54. DOI: 10.5815/ijisa.2019.05.06.

[15] Shyam R. Sihare (2018), "Roles of E-content for E-business: Analysis", International Journal of Information Engineering and Electronic Business, № 1, 24-30. DOI: 10.5815/ijieeb.2018.01.04

[16] Purba D. Kusuma, Azhari, Reza Pulungan (2016), "Agent-Based Crowd Simulation of Daily Goods Traditional Markets", International Journal of Intelligent Systems and Applications, № 10, pp. 1-10. DOI: 10.5815/ijisa.2016.10.01 